\title{
PENGARUH SENAM NIFAS TERHADAP PENURUNAN TINGGI FUNDUS UTERI PADA IBU POST PARTUM DI KLINIK BUDI MULIA MEDIKA TAHUN 2018
}

\section{Tirta Anggraini}

Akademi Kebidanan Budi Mulia Palembang

\section{Informasi Artikel :}

Diterima : November 2018

Disetujui : Desember 2018

"Korespondensi Penulis :

tirtaanggraini1705@gmail.com

\begin{abstract}
A B S T R A K
Masa nifas (puerpenium) adalah masa sesudah melahirkan.yang berlansung selama kurang lebih 6 minggu,Perdarahan merupakan salah satu sebab utama kematian ibu dalam masa nifas yaitu berkisar $5-15 \%$. Penyebab dari perdarahan tersebut yaitu $50-60 \%$ tidak adanya kontraksi uterus, Data World health organization ((WHO), mencatat bahwa angka ibu nifas meningkat setiap tahunnya. Pada tahun 2010 sebanyak $10 \%$ ibu meninggal dunia ketika masa nifas terjadi dalam 24 jam pertama. Sementara pada tahun 2011 jumlah ibu nifas meninggal sebanyak 5\% menurun dari tahun sebelumnya, Salah satu cara yang dapat dilakukan untuk mencegah terjadinya perdarahan pasca persalinan adalah dengan merangsang kontraksi miometrium maka salah satu upaya yang dilakukan adalah senam nifas, Senam nifas merupakan latihan jasmani yang berfungsi untuk mengembalikan kondisi kesehatan, untuk mempercepat penyembuhan, mencegah timbulnya komplikasi, memulihkan dan memperbaiki regangan pada otot-otot setelah kehamilan, terutama pada otototot bagian punggung, dasar panggul, dan perut. Tujuan dari penelitian ini adalah untuk mengetahui apakah ada pengaruh senam nifas terhadap penurunan tinggi fundus uteri pada ibu post partum.Penelitian ini menggunakan desain penelitian kuantitatif dengan pendekatan desain post test only desain. Sampel dalam penelitian ini adalah ibu nifas yang berkunjung ke Klinik Budi Mulia Medika Palembang tahun 2018 Yang berjumlah 30 orang. Analisa data yang digunakan analisa univariat dan bivariat. Hasil penelitian ini menunjukan responden yang melakukaan senam nifas 23 orang $(76,7 \%)$ dan tidak senam nifas 7 orang $(23,3 \%)$. Dan responden yang penurunan tinggi fundus baik 19 orang $(63,3 \%)$ dan penurunan tinggi fundus kurang baik 16 orang $(84,2 \%)$. Berdasarkan hasil uji Chi-Square didapatkan hubungan bermakna antara senam nifas dengan penurunan tinggi fundus $\rho$ value $=0,032$. Diharapkan bidan dapat memberikan informasi lengkap mengenai manfaat senam nifas pada ibu nifas dimulai sejak obu hamil. Sehingga ibu hamil mengetahui cara melakukan dan keuntungan dari senam nifas terhadap penurunan tinngi fundus uteri pada ibu nifas.
\end{abstract}

Kata Kunci : Senam Nifas, Penurunan Tinggi Fundus Uteri

\section{ABSTRACT}

Postpartum period (puerpenium) is the postpartum period which lasts for approximately 6 weeks, Bleeding is one of the main causes of maternal death in the period of nifas, which ranges from 5-15\%. The cause of the bleeding is 50-60\% in the absence of uterine contractions, Data World health organization ((WHO), notes that the number of postpartum mothers increases every year. In 2010 as many as 10\% of mothers died when the puerperium occurred in the first 24 hours. While in 2011 the number of postpartum mothers died as much as 5\% decreased from the previous year. One way that can be done to prevent the occurrence of postpartum hemorrhage is to stimulate myometrial contraction so one of the efforts taken is puerperal gymnastics, puerperal gymnastics is a functional physical exercise to restore health conditions, to accelerate healing, prevent complications, restore and improve strain on the muscles after pregnancy, especially in the muscles of the back, pelvic floor and abdomen.The aim of this study was to determine whether there were effects of puerperal gymnastics to decrease in fundal uterine height in post 


\begin{abstract}
p mothers artum. This study uses a quantitative research design with a post test only design design approach. The sample in this study was postpartum mothers who visited the Budi mulia Palembang clinic in 2018 which numbered 30 people. Data analysis used univariate and bivariate analysis. The results of this study showed that respondents who performed puerperal exercise 23 people (76.7\%) and not postpartum gymnastics 7 people (23.3\%). And respondents who decreased fundal height were 19 people (63.3\%) and fundal height reduction was 16 people (84.2\%). Based on the results of the Chi-Square test found a significant relationship between puerperal gymnastics with a decrease in fundal height $\rho$ value $=0.032$. It is expected that midwives can provide complete information about the benefits of postpartum gymnastics in postpartum mothers starting from a pregnant obu. So that pregnant women know how to do and benefit from puerperal gymnastics to decrease the fundus uterine energy in postpartum mothers.
\end{abstract}

Keywords: puerperal gymnastics, fundal height reduction.

\title{
PENDAHULUAN
}

Masa nifas (puerpenium), berasal dari bahasa Latin, puer yang artikan bayi dan parous yang artinya masa sesudah melahirkan. Masa nifas berangsur kurang lebih 6 minggu. Pada masa nifas, alat-alat genetalia interna maupun eksterna akan berangsur-angsur pulih kembali seperti keadaan sebelum hamil. Perubahanperubahan alat-alat genital ini dalam keseluruhannya di sebut involusi (Ambarwati, 2009)

Menurut laporan Badan Kesehatan Dunia (WHO), mencatat bahwa angka ibu nifas meningkat setiap tahunnya. Pada tahun 2010 diperkirakan $60 \%$ atau sekitar 598.000 dari jumlah tersebut sebanyak $10 \%$ ibu meninggal dunia ketika masa nifas terjadi dalam 24 jam pertama. Pada tahun 2011 ibu nifas sebanyak 80\% atau sekitar 860.000 dan yang meninggak dunia sekitar $20 \%$. Sementara pada tahun 2012 jumlah ibu nifas mengalami peningkatan 5\% dari tahun sebelumnya atau sekitar 928.000 dengan angka kematian ibu nifas sebanyak 398.000( WHO 2017).

Hasil berupa survei secara acak tentang efek senam nifas pada 1003 wanita Amerika mengaku setelah mengikuti program senam nifas dengan latihan yang teratur mengalami pengerutan pada rahim yang lebih kuat, selain itu juga mengalami penurunan pada berat badan selama enam minggu setelah melahirkan. Dan dalam studi dari 1432 ibu nifas di Swedia yang melakukan senam nifas ditemukan bahwa mayoritas $71 \%$ wanita tersebut mengalami metabolisme tubuh yang lancar, dan pemulihan fisik yang lebih cepat (Larson, 2002).

Hasil penelitian yang dilakukan oleh Purwaningrum (2011) tentang Pengaruh Senam Nifas Kecepatan Penurunan Tinggi Fundus Uteri pada Ibu Post Partum Primipara Hari 1-5 di Puskesmas Mergangsan Malang didapatkan hasil pada kelompok intervensi sebelum dilakukan senam nifas rata-rata TFU adalah $11,75 \mathrm{~cm}$ dengan standar deviasi $0,67 \mathrm{~cm}$. setelah dilakukan senam nifas diperoleh rata-rata TFU adalah 7,35 $\mathrm{cm}$ dengan standar deviasi $0,67 \mathrm{~cm}$. Nilai rata-rata perbedaan antara pengukuran pertama dan pengukuran kedua adalah $4,4 \mathrm{~cm}$ dengan standar, deviasi 10,67 cm. Maka dapat disimpulkan ada pengaruh senam nifas terhadap invulusi uterus, yaitu perbedaan yang signifikan pada TFU sebelum dan setelah dilakukan senam nifas. Masa nifas berlangsung selama lebih kurang 6 minggu (Suharmi ,2009)

Di Indonesia jumlah ibu nifas dalam beberapa tahun terakhir terlihat mengalami peningkatan sedangkan angka kematian ibu nifas mengalami penurunan. Pada tahun 2009 angka ibu nifas di perkirakan sebesar 96.000 dengan jumlah kematian sebanyak 12\%. Pada tahun 2010 sebanyak 125.000 ibu nifas dengan angka kematian 7\%. Sedangkan pada tahun 2011 jumlah ibu nifas sebanyak 176.000 dengan angka kematian sebanyak 4\%. Sementara pada tahun 2012 jumlah ibu nifas sebanyak 198.300 dengan angka kematian ibu sebanyak 3\% (Kasjono : 2012).

Perdarahan merupakan salah satu sebab utama kematian ibu dalam masa perinatal yaitu berkisar 5-15\% dari seluruh persalinan. Penyebab terbanyak dari perdarahan post partum tersebut yaitu $50-60 \%$ karena kelemahan atau tidak adanya kontraksi uterus (Ambarwati, 2009)

Berdasarkan data yang didapat dari Dinas Propinsi Sumatera Selatan AKI pada tahun 2011 adalah 467/100.000 kelahiran hidup, sedangkan AKI disebabkan karena perdarahan yaitu 45 kasus 
(0,03\%) dari 174.618 persalinan. Pada tahun 2012 AKI yang disebabkan karena perdarahan sebanyak 43 kasus $(0,02 \%)$ dari 177.058 persalinan. (Profil Dinas Kesehatan Prop. Sum-Sel,2017).

Cakupan pelayanan nifas di kota Palembang tahun 2017 mencapai 91,06\% sudah memenuhi target pelayanan minimum yaitu 90\% (Dinkes kota palembang, 2017).

Berdasarkan data yang di dapat dari dinas kesehatan kota Palembang tahun 2014 ibu nifas sebanyak 33,768 jiwa dan pada tahun 2015 ibu nifas sebanyak 34,768 jiwa sedangkan pada tahun 2016 jumlah ibu nifas sebanyak 31,152 (Dinas Kesehatan Kota Palembang 2017 )

Penyebab perdarahan setelah melahirkan yang paling sering ialah atonia uteri yaitu kegagalan otot rahim untuk berkontraksi dengan kuat. Atonia uteri adalah suatu keadaan dimana uterus gagal untuk berkontraksi dan mengecil sesudah janin keluar dari rahim. Atonia uteri terjadi ketika myometrium. tidak berkontraksi. Salah satu cara yang dapat dilakukan untuk mencegah terjadinya perdarahan pasca persalinan adalah dengan merangsang kontraksi miometrium maka salah satu upava yang dilakukan adalah senam nifas (Depkes, RI, 2008).

Involusi adalah suatu proses dimana uterus kembali ke kondisi sebelum hamil dengan berat sekitar 60 gram. Proses ini dimulai segera setelah plasenta lahir akibat kontraksi otot-otot polos uterus. Involusi disebabkan oleh kontraksi dan retraksi serabut otot uterus yang terjadi terus-menurus. Apabila terjadi kegagalan involusi uterus untuk kembali pada keadaan tidak hamil maka akan menyebabkan sub involusi (Ambarwati, 2009)

Gejala dari sub involusi meliputi lochea menetap/merah segar, penurunan fundus uteri lambat, tonus uteri lembek, tidak ada perasaan mules pada ibu nifas akibatnya terjadi pendarahan. Perdarahan pasca persalinan adalah kehilangan darah lebih dari $500 \mathrm{ml}$ melalui jalan lahir yang terjadi selama atau setelah persalinan kala III. Perkirakan kehilangan darah biasanya tidak sebanyak yang sebenarnya, kadang-kadang hanya setengah dari yang sebenarnya (Anggraini, 2010).

Pendarahan yang masif berasal dari tempat implantasi plasenta, robekan pada jalan lahir dan jaringan sekitarnya merupakan salah satu penyebab kematian ibu disamping perdarahan karena hamil ektopik dan abortu Senam nifas merupakan latihan jasmani yang berfungsi untuk mengembalikan kondisi kesehatan, untuk mempercepat penyembuhan, mencegah timbulnya komplikasi, memulihkan dan memperbaiki regangan pada otot-otot setelah kehamilan, terutama pada otot-otot bagian punggung, dasar panggul, dan perut (Ambarwati, 2009)

Menurut Bobak (2004) penyebab perdarahan setelah melahirkan yang paling sering ialah atonia uteri yaitu kegagalan otot rahim untuk berkontraksi dengan kuat. Atonia uteri adalah suatu keadaan dimana uterus gagal untuk berkontraksi dan mengecil sesudah janin keluar dari rahim. Atonia uteri terjadi ketika myometrium. tidak berkontraksi. Salah satu cara yang dapat dilakukan untuk mencegah terjadinya perdarahan pasca persalinan adalah dengan merangsang kontraksi miometrium maka salah satu upava yang dilakukan adalah senam nifas (Depkes, RI, 2003).

Para ibu pasca melahirkan takut melakukan banyak gerakan, sang ibu khawatir gerakangerakan yang akan dilakukannya akan menimbulkan dampak yang tidak diinginkan. Padahal, apabila ibu bersalin melakukan ambulasi dini, itu bisa memperlancar terjadinya involusi uterus. Dan pada umumnya wanita yang telah melahirkan sering mengeluh bagian tubuhnya melar, bahkan kondisi tubuhnya kurang prima akibat letih dan tegang. Sementara peredaran darah dan pernafasan belum kembali normal, sehingga untuk membantu mengembalikan tubuh ke bentuk dan kondisi semula harus melakukan senam nifas yang teratur (Jurnal Kesehatan FORIKES, 2011).

Ada beberapa faktor yang mempengaruhi involusi uterus. Faktor-faktor tersebut meliputi senam nifas, mobilisasi dini post partum, menyusui dini, gizi, psikologis, faktor usia dan paritas ((Ambarwati, 2009)

Menurut Huliana (2005) salah satu faktor yang mempercepat involusi adalah senam nifas yaitu bentuk ambulansi dini pada ibu-ibu nifas yang salah satu tujuannya untuk memperlancar proses involusi,sedangkan ketidaklancaran proses involusi dapat berakibat buruk pada ibu nifas seperti terjadi perdarahan yang bersifat lanjut dan kelancaran proses involusi.

Manfaat senam nifas diantaranya adalah membantu penyembuhan rahim, perut, dan otot pinggul yang mengalami trauma serta mempercepat kembalinya bagian-bagian tersebut ke bentuk normal, membantu menormalkan sendi-sendi yang menjadi longgar akibat kehamilan dan persalinan, serta mencegah pelemahan dan peregangan lebih lanjut. Latihan senam nifas dapat segera dimulai dalam waktu 24 jam setelah melahirkan lalu secara teratur setiap hari (Bobak, 2004).

Namun perlu diketahui bentuk latihan senam nifas ibu pasca melahirkan normal dengan yang 
melahirkan dengan sesar tidak sama. Pada ibu yang melahirkan dengan cara sesar beberapa jam setelah keluar kamar operasi, latihan pernafasan dilakukan untuk mempercepat penyembuhan luka. Sementara latihan untuk mengencangkan otot perut dan melancarkan sirkulasi darah dibagian tungkai dapat dilakukan 2-3 hari setelah ibu dapat bangun dari tempat tidur. Sedangkan pada persalinan normal, bila keadaan ibu sudah cukup baik, maka semua gerakan senam nifas dapat dilakukan (Widianti, 2010).

Penurunan ukuran uterus yang cepat itu dicerminkan oleh perubahan lokasi uterus ketika turun keluar dari abdomen dan kembah menjadi organ pelviks. Segera setelah proses persalinan puncak fundus kira-kira dua pertiga hingga tiga perempat dari jalan atas diantara simfisis pubis dan umbilikus. Kemudian naik ke tingkat umbilikus dalam beberapa jam dan bertahan hingga dua atau dua hari dan kemudian secara berangsur-angsur turun ke pelviks yang secara abdominal tidak dapat terpalpasi di atas simfisis setelah sepuluh hari ((Ambarwati, 2009)

Kegagalan uterus untuk kembali pada keadaan tidak hamil atau disebut dengan subinvolusi. Penyebab subinvolusi yang paling sering ialah tertahannya fragmen plansenta dan infeksi (Bobak, 2004).

Masa ini ibu membutuhkan latihan- latihan tertentu yang dapat mempercepat proses involusi. Involusi uterus meliputi reorganisasi dan pengeluaran desidua/ endometrium dan eksfoliasi tempatperlekatan plasenta yang ditandai dengan penurunan ukuran dan berat serta perubahan lokasi uterus yang ditandai dengan warna dan jumlah lokia. Apabila terjadi kegagalan involusi uterus untuk kembali pada keadaan tidak hamil maka akan menyebabkan sub involusi. Penyebab sub involusi uteri yang paling sering adalah tertahannya fragmenplasenta, infeksi, dan perdarahan lanjut (late postpartum haemorrhage) (Bobak, 2004).

Untuk mempercepat proses involusi uteri, salah satu latihan yang dianjurkan adalah senam nifas Senam nifas adalah latihan jasmani yang dilakukan oleh ibu-ibu setelah melahirkan setelah keadaan tubuhnya pulih kembali. Fungsinya adalah untuk mengembalikan kondisi kesehatan, untuk mempercepat penyembuhan, mencegah timbulnya komplikasi, memulihkan dan memperbaiki regangan pada otot-otot setelah kehamilan, terutama pada otot-otot bagian punggung, dasar panggul, dan perut. (Bobak, 2004).

Manfaat melakukan senam nifas adalah memulihkan kembali kekuatan otot dasar panggul, mengencangkan otot-otot dinding perut dan perinium, membentuk sikap tubuh yang baik dan mencegah terjadinya komplikasi. Komplikasi yang dapat dicegah sedini mungkin dengan melaksanakan senam nifas adalah perdarahan post partum. Saat melaksanakan senam nifas terjadi kontraksi otot-otot perut yang akan membantu proses involusi yang mulai setelah plasenta keluar segera setelah proses involusi (Widianti, 2010).

Berdasarkan latar belakang diatas maka penulis tertarik untuk melakukan penelitian yang berjudul "Pengaruh Senam Nifas Terhadap Penurunan Tinggi Fundus Uteri Pada Ibu Post Partum Di Klinik Budi Mulia Medika Tahun 2018"

\section{METODE PENELITIAN}

Desain penelitian yang digunakan dalam penelitian ini adalah eksperimen semu (Quasi Eksperiment) mengingat tidak semua variabel (gejala yang muncul) dan kondisi ekperimen dapat diatur dan dikontrol secara ketat (Notoatmodjo, 2010).

Penelitian ini bertujuan untuk mencari pengaruh model pembelajaran yang digunakan terhadap hasil belajar dalam pembelajaran untuk senam nifas pada ibu nifas. Populasi penelitian ini adalah seluruh ibu nifas yang datang ke klinik budi mulia Medika Palembang pada saat penelitian berlangsung.

Penelitian ini adalah tergolong penelitian semu (Quasi Eksperimen), desain penelitian ini menggunakan "Posttest-Only Design".

Variabel Independen Variabel Dependen

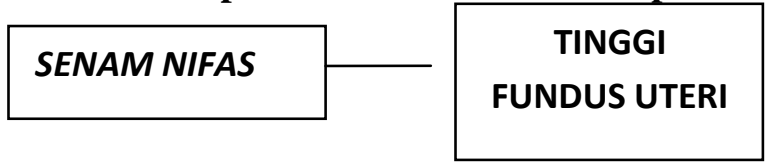

\section{Bagan Kerangka Konsep}

Populasi dalam penelitian ini adalah semua ibu Nifas yang berkunjung ke Klinik Budi Mulia Medika Palembang Tahun 2018 pada bulan Februari - April sebanyak 65 orang

Sampel pada penelitian ini yaitu sebagian ibu Nifas yang berkunjung ke Klinik Budi Mulia Medika Palembang Tahun 2018 pada bulan September-Desember Sebanyak 30 orang. Sampel diambil dengan menggunakan tekhnik Proporsive Sampling yaitu pengambilan sampel pada saat dilakukan penelitian

Analisa univarat bertujuan untuk menggambarkan secara sistematis fakta atau karakteristik populasi tertentu atau bidang tertentu secara aktual dan cermat. Analisa yang dimaksud 
Jurnal Kebidanan : Jurnal Medical Science Ilmu Kesehatan Akademi Kebidanan Budi Mulia Palembang Volume.8 No.2, Desember 2018

untuk mendeskripsikan masing-masing variabel independen yaitu Senam nifas pada ibu nifas, variabel dependen penurunan tinggi fundus uteri

Analisa bivarat dilakukan berdasarkan uji chi-square untuk menemukan bentuk hubungan statistik antara variabel independen (Senam nifas) dan variabel dependen (penurunan tinggi fundus uteri). Hasil analisis bivarat merupakan hubungan antara masing-masing variabel dependen dan independen

Analisa bivariat dilakukan terhadap dua variabel yang diduga berhubungan. Untuk membuktikan apakah hipotesa diterima / ditolak, dengan menggunakan $\mathrm{x}^{2}$ (chi square).

\section{HASIL PENELITIAN}

\section{Analisis Univariat}

Analisis univariat yaitu analisis yang dilakukan terhadap satu variabel. Analisis ini dilakukan pada setiap variabel yang diteliti.

Tabel 1 Distribusi Frekuensi Senam nifas ibu Nifas di klinik Budi Mulia Medika Palembang 2018

\begin{tabular}{llll}
\hline No & Senam Nifas & Frekuensi & Persentase \\
\hline 1 & Sering & 23 & 76,7 \\
\hline 2 & Jarang & 7 & 23,3 \\
\hline & Total & $\mathbf{3 0}$ & $\mathbf{1 0 0}$ \\
\hline
\end{tabular}

Berdasarkan tabel 1 di atas didapatkan bahwa sebagian besar ibu hamil sering melakukan Senam nifas yaitu sebanyak 22 responden $(73,3)$.

Tabel 2 Distribusi Frekuensi Penurunan tinggi fundus uteri Pada Ibu di klinik Budi Mulia Medika Palembang

\begin{tabular}{cccc}
\hline No & $\begin{array}{c}\text { Tinggi } \\
\text { fundus }\end{array}$ & Frekuensi & Persentase \\
\hline 1 & Baik & 19 & 63,3 \\
\hline 2 & Kurang & 11 & 36,7 \\
\hline & Total & $\mathbf{3 0}$ & $\mathbf{1 0 0}$ \\
\hline & Berdasarkan & tabel 2 & diatas dapat
\end{tabular}

diketahui bahwa 30 responden, yaitu

Penurunan tinggi fundus uteri dengan baik sebnayak 19 responden $(63,3 \%)$.

\section{Analisis Bivariat}

Analisis bivariat adalah analisis yang dilakukan terhadap dua variabel yang diduga berhubungan. Dalam penelitian ini analisis bivariat digunakan untuk mengetahui Hubungan senam nifas terhadap Penurunan Tinggi Fundus uteri ibu Nifas di klinik Budi Mulia Medika
Palembang 2018 Untuk mengetahui hubungan ini digunakan uji Chi Square dimana hasilnya disajikan pada tabel berikut ini.

Tabel 3 Hubungan senam nifas terhadap Penurunan Tinggi Fundus uteri ibu Nifas di klinik Budi Mulia Medika Palembang 2018

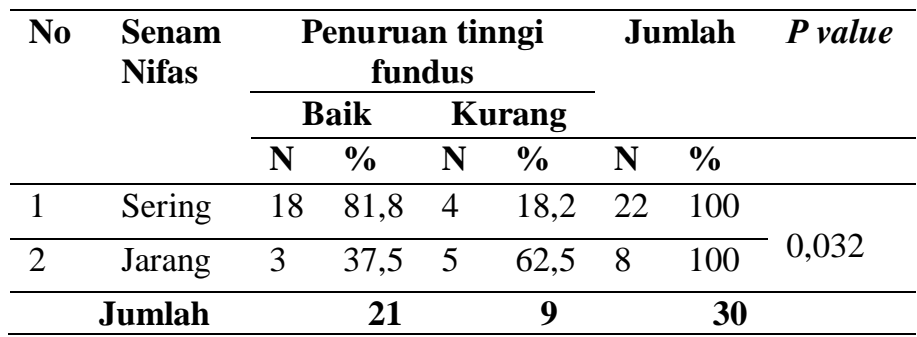

Berdasarkan tabel 3 diatas, didapatkan dari 22 responden yang sering melakukan senam nifas dengan penurunan fundus baik berjumlah 18 orang $(81,8 \%)$, dan dengan jenis persalinan buatan/tindakan berjumlah 4 orang $(18,2 \%)$ lebih kecil bila dibandingkan dari 8 responden yang jarang melakukan senam nifas dengan penurunan fundus kurang baik berjumlah 3 orang $(37,5 \%)$, dan dengan jenis persalinan buatan/tindakan berjumlah 5 orang $(62,5 \%)$.

Hasil uji statistik chi-square didapatkan $\rho$ value $=0,032$. Ini berarti $\rho$ value lebih kecil dari $\alpha$ $=0,05$. berarti ada hubungan yang bermakna senam nifas dengan penurunan fundus uteri pada ibu nifas di Klinik Budi Mulia medika Palembang tahun 2018

Sehingga hipotesis alternatif $(\mathrm{Ha})$ yang menyatakan bahwa ada hubungan antara senam nifas dengan penurunan fundus uteri pada ibu nifas diterima, dan hipotesis nol (Ho) yang menyatakan bahwa tidak ada hubungan antara senam nifas dengan penurunan fundus uteri pada ibu nifas ditolak dengan terbukti secara statistik.

\section{PEMBAHASAN}

\section{Senam Nifas}

Hasil analisa univariat dalam penelitian di Klinik Budi mulia medika Palembang tahun 2018 ini variabel senam nifas dikategorikan menjadi dua yaitu : sering, jarang. Sering jika responden melakukan senam nifas $\geq 5 \mathrm{x} /$ minggu, jarang jika responden melakukan senam nifas $<5 \mathrm{x} /$ minggu. Dari hasil penelitian didapatkan responden yang sering melakukan senam nifas sebanyak 22 responden $(73,3 \%)$, lebih banyak dibanding dengan responden yang jarang melakukan senam nifas sebanyak 8 responden $(26,7 \%)$. 
Hasil analisa bivariat didapatkan dari 22 responden yang sering melakukan senam nifas dengan penurunan tinggi fundus uteri baik berjumlah 18 orang $(81,8 \%)$, dan dengan penurunan tinggi fundus uteri kurang baik erjumlah 4 orang $(18,2 \%)$ lebih kecil bila dibandingkan dari 8 responden yang jarang melakukan senam nifas dengan penurunan tinggi fundus uteri baik berjumlah 3 orang $(37,5 \%)$, dan dengan penurunan tinggi fundus uteri kurang baik berjumlah 5 orang $(62,5 \%)$.

Hasil uji statistik chi-square didapatkan $\rho$ value $=0,032$. Ini berarti $\rho$ value lebih kecil dari $\alpha=0,05$. berarti ada hubungan yang bermakna senam nifas dengan penurunan fundus uteri pada ibu nifas di Klinik Budi Mulia medika Palembang tahun 2018

Hasil penelitian yang dilakukan oleh Yuniasih Purwaningrum (2011) tentang Pengaruh Senam Nifas Kecepatan Penurunan Tinggi Fundus Uteri pada Ibu Post Partuni Primipara Hari 1-5 di Puskesmas Mergangsan Malang didapatkan hasil pada kelompok intervensi sebelum dilakukan senam nifas rata-rata TFU adalah $11,75 \mathrm{~cm}$ dengan standar deviasi $0,67 \mathrm{~cm}$. setelah dilakukan senam nifas diperoleh rata-rata $\mathrm{TFU}$ adalah 7,35 $\mathrm{cm}$ dengan standar deviasi $0,67 \mathrm{~cm}$. Nilai rata-rata perbedaan antara pengukuran pertama dan pengukuran kedua adalah 4,4 $\mathrm{cm}$ dengan standar, deviasi 10,67 cm. Maka dapat disimpulkan ada pengaruh senam nifas terhadap invulusi uterus, yaitu perbedaan yang signifikan pada TFU sebelum dan setelah dilakukan senam nifas.

6 minggu. Masa ini ibu membutuhkan latihan- latihan tertentu yang dapat mempercepat proses involusi. Involusi uterus meliputi reorganisasi dan pengeluaran desidua/ endometrium dan eksfoliasi tempatperlekatan plasenta yang ditandai dengan penurunan ukuran dan berat serta perubahan lokasi uterus yang ditandai dengan warna dan jumlah lokia. Apabila terjadi kegagalan involusi uterus untuk kembali pada keadaan tidak hamil maka akan menyebabkan sub involusi. Penyebab sub involusi uteri yang paling sering adalah tertahannya fragmenplasenta, infeksi, dan perdarahan lanjut (late postpartum haemorrhage) Untuk mempercepat proses involusi uteri, salah satu latihan yang dianjurkan adalah senam nifas

Senam nifas adalah latihan jasmani yang dilakukan oleh ibu-ibu setelah melahirkan setelah keadaan tubuhnya pulih kembali.
Fungsinya adalah untuk mengembalikan kondisi kesehatan, untuk mempercepat penyembuhan, mencegah timbulnya komplikasi, memulihkan dan memperbaiki regangan pada otot-otot setelah kehamilan, terutama pada otot-otot bagian punggung, dasar panggul, dan perut ${ }^{5}$.

Manfaat melakukan senam nifas adalah memulihkan kembali kekuatan otot dasar panggul, mengencangkan otot-otot dinding perut dan perinium, membentuk sikap tubuh yang baik dan mencegah terjadinya komplikasi. Komplikasi yang dapat dicegah sedini mungkin dengan melaksanakan senam nifas adalah perdarahan post partum. Saat melaksanakan senam nifas terjadi kontraksi otot-otot perut yang akan membantu proses involusi yang mulai setelah plasenta keluar segera setelah proses involusi

Menurut Dewi (2011), senam nifas merupakan latihan jasmani yang berfungsi untuk mengembalikan kondisi kesehatan, umuk mempercepat penyembuhan, mencegah timbulnya komplikasi, memulihkan dan memperbaiki regangan pada otot-otot setelah kehamilan, terutama pada otot-otot bagian punggung, dasar panggul, dan perut.

Senam nifas mempunyai pengaruh yang bermakna terhadap penurunan tinggi fundus uteri, kontraksi uterus dan pengeluaran lochea pada ibu pasca salin hari I-III, dengan nilai masing-masing $\mathrm{p}=0,00$. Hal ini terjadi karena dengan melakukan senam nifas akan memperlancar aliran darah dan meningkatkan tonus otot-otot uterus, akibatnya proses autolysis menjadi lancar, kontraksi uterus menjadi lebih kuat dan pengeluaran lochea semakin cepat (Jurnal Kesehatan FORIKES, 2011).

Hasil penelitian ini juga didukung oleh Larson berupa survei secara acak tentang efek senam nifas pada 1003 wanita Amerika mengaku setelah mengikuti program senam nifas dengan latihan yang teratur mengalami pengerutan pada rahim yang lebih kuat, selain itu juga mengalami penurunan pada berat badan selama enam minggu setelah melahirkan. Dan dalam studi dari 1432 ibu nifas di Swedia yang melakukan senam nifas ditemukan bahwa mayoritas $71 \%$ wanita tersebut mengalami metabolisme tubuh yang lancar, dan pemulihan fisik yang lebih cepat (Huliana M, 2003). 
Jurnal Kebidanan : Jurnal Medical Science Ilmu Kesehatan Akademi Kebidanan Budi Mulia Palembang Volume.8 No.2, Desember 2018

\section{KESIMPULAN}

Dari data yang berhasil dikumpulkan dalam penelitian ini telah diperoleh hubungan yang bermakna senam nifas dengan penurunan fundus uteri pada ibu nifas di Klinik Budi Mulia medika Palembang tahun 2018. Setelah dijelaskan secara rinci pada bab sebelumnya, peneliti mencoba menyimpulkan beberapa hal diantaranya :

1. Distribusi frekuensi responden yang melakukan senam nifas sebanyak 22 responden $(73,3 \%)$.

2. Distribusi frekuensi responden yang penurunan tinggi fundus sebanyak 19 responden $(63,3 \%)$.

3. Ada hubungan yang bermakna senam nifas dengan penurunan fundus uteri pada ibu nifas di Klinik Budi Mulia medika Palembang tahun 2018 (pvalue $=0,032$ )

\section{DAFTAR PUSTAKA}

Ambarwati, R. \&. (2009). Asuhan Kebidanan Nifas. Yogyakarta: Mitra Cendekia Press

Anggraini, Y. (2010). Asuhan Kebidanan Masa Nifas. Yogyakarta: Pustaka ID

Rihama.Arikunto. (2010). Prosedur Penelitian. Jakarta: Rineka Cipta.

Biro Pusat Statistik. 2003. Survei Demografi dan Kesehatan 2003. Jakarta: Depkes RI. Bobak. (2004). Buku Ajar Keperawatan Maernitas. Jakarta: EGC.

Cunningham, F. G. (2005). Obstetri Williams. Jakarta: EGC.

Dewi, V. N. (2011). Asuhan Kebidanan pada Ibu Nifas. Jakarta: Salemba Medika.

Huliana, M. (2003). Perawatan Ibu Pasca Melahirkan. Jakarta: Puspa Swara.

Hulu, R. (2012). Pengaruh Menyusui terhadap Percepatan Penurunan Tinggi Fundus Uteri pada Ibu Post Partum Hari Pertama dan Kedua di Klinik Ernawati Pancur Batu Medan Tahun 2012. Skripsi. Medan: Sekolah Tinggi Ilmu Kesehatan Sumatura Utara.

Kasjono, H. S., \& Yasril. (2009). Teknik Sampling untuk Penelitian Kesehatan. Yogyakarta: Graha Ilmu.

Notoatmodjo, S. (2002). Metodologi Penelitian Salemba Medika.
Prawirohardjo, S. (2006). Ilmu Kebidanan. Jakarta: Yayasan Bina Pustaka

Sarwono Prawirohardjo. Pusdiknakes-WHOJHPIEGO. $2003 . \quad$ Asuhan Kebidanan Post Partum. Buku 4. Jakarta

Purwaningrum, Y. (2011). Pengaruh senam Nifas terhadap Kecepatan Penurunan Tinggi Fundus Uteri padaA Ibu Post Partum Primipara Hari Pertarna sampai Hari Ke Lima di Puskesmas Mergangsan. Jurnal Penelitian Kesehatan Suara Forikes 2086-3098.

Roito, J. (2010). Asuhan Kebidanan Thu Nifas. Jakarta: 2010. Rustam. (1998). Sinopsis Obstetri. Jakarta: EGC.

Saleha. (2009). Asuhan Kebidanan pada Masa Nifas. Jakarta: EGC.

Suherni, W.d. (2009). Perawatan Masa Nifas. Jakarta.EGC

Sulistyawati, A. (2009). Baku Ajar Asuhan Kebidanan pada Ibu Nifas. Jakarta: Andi.

Sunarsih, V. d. (2011). Asuhan Kebidanan pada Ibu Nifas. Jakarta: Salemba Medika.

Toyibah, A. 2003. Pengaruh Senam Nifas Terhadap Percepatan Turunnya Fundus Uteri Pada Hari PeRTama Pasca Salin di Ruang BerSalin II Dr. Soetomo Surabaya. Skripsi. Surabaya,

Varney, H. (2004). Buku Ajar Asuhan Kebidanan Edisi 4 Volume 2. Jakarta: EGC.

Widianti. (2010). Asuhan Kebidanan Masa Nifas. Jakarta: EGC.

Wiknjosastro, H. (2005). Ilmu Bedah Kebidanan. Jakarta: Yayasan Bina Pustaka.

Sarwono Prawiroharjo. Yustanto, T. J. (2008). Senam Nifas terhadap Involusi Uteri. Jurnal Kesehatan, Hubungan Pemanfaatan Bidan dengan Cakupan Program, Jakarta

Notoatmodjo Soekidjo, 2002, Metode Penelitian Kesehatan. Rineka Cipta, Jakarta

Untuk Kedokteran dan Kesehatan, Jakarta 
Jurnal Kebidanan : Jurnal Medical Science Ilmu Kesehatan Akademi Kebidanan Budi Mulia Palembang Volume.8 No.2, Desember 2018

Wiknjosastro Hanafi, 2005, Ilmu Kebidanan,

Yayasan Bina Pustaka, YogyakartA , 2009, Ilmu Kebidanan, Yayasan Bina Pustaka, Yogyakarta Kesehatan. Jakarta: Rineka Cipta.

Nursalam. (2003). Konsep Dan Penerapan Metodologi Penelitian Ilmu Keperawatan. Jakarta: 
